\title{
Synthesis and Radical Ring-Opening Polymerization Behavior of Vinylcyclopropanes Bearing Cyclic Thioacetal Moieties
}

\author{
Tadashi OKaZaki, Fumio SANDa, and Takeshi $\mathrm{ENDO}^{\dagger}$ \\ Research Laboratory of Resources Utilization, Tokyo Institute of Technology, \\ Nagatsuta-cho, Midori-ku, Yokohama 226-8503, Japan
}

(Received June 3, 1997)

\begin{abstract}
The synthesis and radical ring-opening polymerizations of vinylcyclopropanes bearing six-, seven-, and eight-membered cyclic thioacetal moieties, 1-vinyl-4,8-dithiospiro[2.5]octane (4), 1-vinyl-4,9-dithiospiro[2.6]nonane (5), and 1-vinyl-4,10-dithiospiro[2.7] decane (6) were carried out. Monomers $4-6$ were prepared by reactions of 1,1-dichloro-2vinylcyclopropane and corresponding dithiols in $N, N$-dimethylformamide (DMF) in the presence of a base. Radical polymerizations of 4,5 , and 6 were carried out at 60,80 , and $120^{\circ} \mathrm{C}$ for $20 \mathrm{~h}$ in the presence of an appropriate initiator $(3 \mathrm{~mol} \%$ $v s$. monomer) to obtain polymers with $M_{n} 600-3100$, mainly consisting of a 1,5-ring-opened unit and a unit with no olefinic moiety.

KEY WORDS Vinylcyclopropane / Cyclic Thioacetal / Radical Ring-Opening Polymerization /
\end{abstract}

Cyclic monomers which undergo ring-opening polymerization are important in the field of materials. ${ }^{1}$ Monomers bearing cyclic acetal moieties are expected to show useful properties. Monomers having spiroacetal moieties have been applied to thermosetting resins. ${ }^{2}$ Sulfur containing polymers should be useful for optical materials because of their high refractive indices. We have reported the synthesis and radical polymerizations of vinylcyclopropanone cyclic acetals $(\mathbf{1}, \mathbf{2}$, and 3 ) to afford polymers via single and double ring-opening processes. ${ }^{3}$ Monomer 1 consisting of a five-membered acetal ring afforded a single ring-opened polymer formed by the cleavage of the bond $a$ distant from the cyclic acetal ring. Monomer 2 consisting of a six-membered acetal ring also afforded a single ring-opened polymer formed by the cleavage of the bond $b$ near the cyclic acetal ring. ${ }^{4}$ Monomer 3 consisting of a seven-membered acetal ring mainly afforded a double ring-opened polymer (Scheme 1). This drastically different polymerization behavior might be explained by differences of the ring-

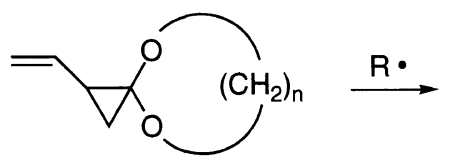

1: $n=2,2: n=3,3: n=4$

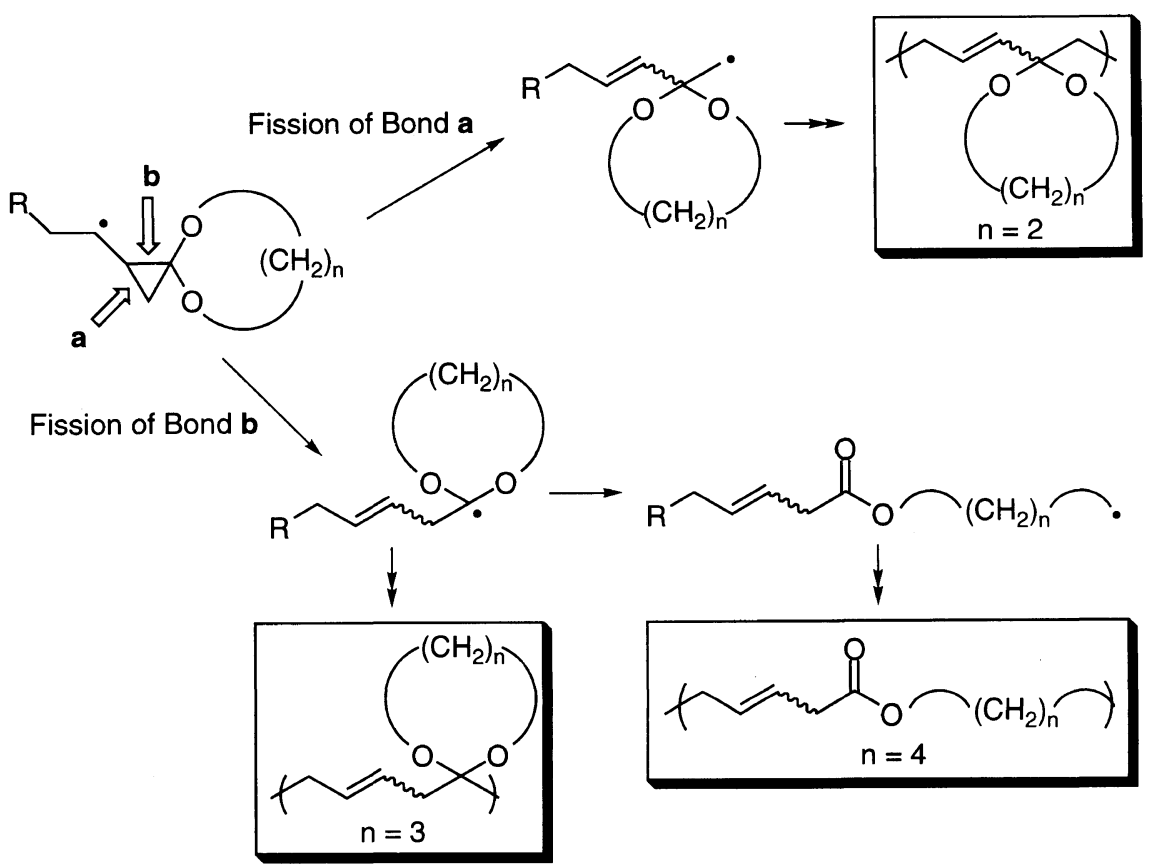

Scheme 1.

\footnotetext{
† To whom all correspondence should be addressed.
} 
strain for the five-, six-, and seven-membered $O$-acetal rings. This paper describes the polymerization behavior of new vinylcyclopropane monomers, vinylcyclopropanone cyclic thioacetals, and the difference of polymerization behavior between the monomers having $O$ - and $S$ cyclic acetal moieties.

\section{EXPERIMENTAL}

\section{Measurements}

${ }^{1} \mathrm{H}$ and ${ }^{13} \mathrm{C}$ NMR spectra of the monomers and polymers were recorded at $27^{\circ} \mathrm{C}$ on JEOL JNM-EX-90 and JNM-EX-400 spectrometers, using tetramethylsilane (TMS) as the internal standard in chloroform- $d\left(\mathrm{CDCl}_{3}\right)$. FT-IR spectra were obtained with a JASCO FT/IR-5300 at $25^{\circ} \mathrm{C}$. Number- and weight-average molecular weights $\left(M_{n}\right.$ and $\left.M_{w}\right)$, and polydispersity ratios $\left(M_{w} / M_{n}\right)$ were determined by gel permeation chromatography (GPC) on a Tosoh HLC-8020 system equipped with four polystyrene gel columns (TSK gels $\mathrm{G} 6000 \mathrm{H}$, G5000H, $\mathrm{G} 4000 \mathrm{H}$, and $\mathrm{G} 2500 \mathrm{H}$ ), using $\mathrm{LiBr}$ solution in $N, N$ dimethylformamide (DMF) $(5.8 \mathrm{mM})$ as an eluent (flow rate $1.0 \mathrm{~mL} \mathrm{~min}^{-1}$ ), polystyrene calibration, and refractive index and ultraviolet detectors. Refractive indices were measured on an Atago Abbe refractometer.

\section{Materials}

Chlorobenzene and DMF were dried and distilled by the usual methods and stored over molecular sieves (4A). Benzyl mercaptan (Tokyo Kasei Kogyo Co., Ltd.), 1,3-propanedithiol (Tokyo Kasei Kogyo Co., Ltd.), 1,4-butanedithiol (Tokyo Kasei Kogyo Co., Ltd.), 1,5pentanedithiol (Aldrich Chemical Co.) were used as received. Initiators 2,2'-azobis(isobutyronitrile) (AIBN, Tokyo Kasei Kogyo Co., Ltd.), benzoyl peroxide (BPO, Nacalai Tesque, Inc.), and di-tert-butyl peroxide (DTBP, Nacalai Tesque, Inc.) were used as received.

\section{Synthesis of 1-Vinyl-4,8-dithiospiro[2.5]octane (4)}

To a mixture of sodium hydride $(2.76 \mathrm{~g}, 110 \mathrm{mmol})$ in DMF $(45 \mathrm{~mL})$, was added a solution of 1,3-propanedithiol $(4.74 \mathrm{~g}, 43.8 \mathrm{mmol})$ in DMF ( $5 \mathrm{~mL})$ dropwise and then a solution of 1,1-dichloro-2-vinylcyclopropane $(6.00 \mathrm{~g}, 43.8 \mathrm{mmol})$ in DMF $(24 \mathrm{~mL})$ at $0^{\circ} \mathrm{C}$. The addition was followed by stirring at room temperature for $20 \mathrm{~h}$. After the reaction, water $(100 \mathrm{~mL})$ was added carefully at room temperature. The mixture was extracted with ether $(120 \mathrm{~mL})$, and the organic layer was washed with a saturated solution of sodium hydrogen carbonate. The organic layer was dried over anhydrous magnesium sulfate and evaporated. The residual liquid was isolated by column chromatography (solvent ; ethyl acetate $/ n$ hexane $=1 / 7$ (volume ratio), and $1 \%$ of triethylamine) to obtain $5.74 \mathrm{~g}$ of $4(76 \%)$ : ${ }^{1} \mathrm{H}$ NMR $\left(\mathrm{CDCl}_{3}\right) \delta$ : $1.07-1.09(\mathrm{~m}, 1 \mathrm{H}), 1.39-1.42(\mathrm{~m}, 1 \mathrm{H}), 1.98-2.16(\mathrm{~m}$, $3 \mathrm{H}), 2.68-3.05(\mathrm{~m}, 4 \mathrm{H}), 5.12(\mathrm{dd}, 1 \mathrm{H}, J=1.24 \mathrm{~Hz}$, $J=10.26 \mathrm{~Hz}), 5.30(\mathrm{dd}, 1 \mathrm{H}, J=1.24 \mathrm{~Hz}, J=17.09 \mathrm{~Hz})$, $5.65-5.74(\mathrm{~m}, 1 \mathrm{H}) .{ }^{13} \mathrm{C} \mathrm{NMR}\left(\mathrm{CDCl}_{3}\right) \delta: 24.78,25.89$, $29.85,30.65,31.88,35.10,116.20,136.88$. IR (neat) 3081 , 2991, 2932, 2901, 2828, 1632, 1422, 1273, 1240, 1211, 1192, 1107, 1028, 990, 905, 868, 833, 772, $413 \mathrm{~cm}^{-1}$. Anal. Calcd for $\mathrm{C}_{8} \mathrm{H}_{12} \mathrm{~S}_{2}$ : C, 55.76\%; H, 7.02\%; S, 37.22\%. Found: C, 55.52\%; H, 7.25\%; S, 37.43\%.
Synthesis of 1-Vinyl-4,9-dithiospiro[2.6]nonane (5)

The compound was prepared from 1,4-butanedithiol and 1,1-dichloro-2-vinylcyclopropane similarly to 4 . Yield 64\%. ${ }^{1} \mathrm{H}$ NMR $\left(\mathrm{CDCl}_{3}\right) \delta: 1.16-1.20(\mathrm{~m}, 1 \mathrm{H})$, $1.52-1.55(\mathrm{~m}, 1 \mathrm{H}), 1.63-1.79(\mathrm{~m}, 1 \mathrm{H}), 2.05-2.16(\mathrm{~m}$, $4 \mathrm{H}), 2.73-2.88(\mathrm{~m}, 4 \mathrm{H}), 5.14(\mathrm{dd}, 1 \mathrm{H}, J=1.20 \mathrm{~Hz}$, $J=10.4 \mathrm{~Hz}), 5.28(\mathrm{dd}, 1 \mathrm{H}, J=1.20 \mathrm{~Hz}, J=16.8 \mathrm{~Hz}$ ), $5.68-5.78(\mathrm{~m}, 1 \mathrm{H}) .{ }^{13} \mathrm{C} \mathrm{NMR}\left(\mathrm{CDCl}_{3}\right) \delta: 26.98,30.43$, $31.24,31.97,32.66,35.88,116.35,137.40$. IR (neat) 3081 , 2920, 2851, 1632, 1437, 1292, 1229, 1117, 1030, 990, 905, $835,683 \mathrm{~cm}^{-1}$. Anal. Calcd for $\mathrm{C}_{9} \mathrm{H}_{14} \mathrm{~S}_{2}: \mathrm{C}, 58.01 \% ; \mathrm{H}$, $7.57 \%$; S, 34.42\%. Found: C, $57.74 \% ; \mathrm{H}, 7.63 \%$; , $34.61 . \%$

\section{Synthesis of 1-Vinyl-4,10-dithiospiro[2.7]decane (6)}

The compound was prepared from 1,5-pentanedithiol and 1,1-dichloro-2-vinylcyclopropane similarly to 4 . Yield $47 \%$. ${ }^{1} \mathrm{H}$ NMR $\left(\mathrm{CDCl}_{3}\right) \delta: 1.08-1.11(\mathrm{~m}, 1 \mathrm{H})$, $1.39-1.45(\mathrm{~m}, 1 \mathrm{H}), 1.51-1.77(\mathrm{~m}, 6 \mathrm{H}), 2.67-2.89(\mathrm{~m}$, $4 \mathrm{H}), 5.08(\mathrm{dd}, 1 \mathrm{H}, J=1.21 \mathrm{~Hz}, J=10.4 \mathrm{~Hz}), 5.23(\mathrm{dd}$, $1 \mathrm{H}, J=1.21 \mathrm{~Hz}, J=17.2 \mathrm{~Hz}), 5.71-5.82(\mathrm{~m}, 1 \mathrm{H}) .{ }^{13} \mathrm{C}$ $\operatorname{NMR}\left(\mathrm{CDCl}_{3}\right) \delta: 27.19,28.57,31.42,31.68,33.32,33.82$, $38.41,39.39,116.31,136.96$. IR (neat) $3081,2926,2852$, 2346, 1634, 1439, 1348, 1298, 1278, 1226, 1188, 1118, 1024, 990, 904, 855, 766, 680, 525, $415 \mathrm{~cm}^{-1}$. Anal. Calcd for $\mathrm{C}_{10} \mathrm{H}_{16} \mathrm{~S}_{2}: \mathrm{C}, 59.95 \% ; \mathrm{H}, 8.05 \% ; \mathrm{S}, 32.00 \%$. Found: C, $60.22 \%$; H, $8.23 \%$; S, 32.26\%.

\section{Reaction of $\mathbf{4}$ and Benzyl Mercaptan}

To $4(0.517 \mathrm{~g}, 3 \mathrm{mmol})$ and benzyl mercaptan $(0.373 \mathrm{~g}$, $3 \mathrm{mmol})$ in a glass tube, were introduced AIBN $(0.0148 \mathrm{~g}$, $0.09 \mathrm{mmol})$ and chlorobenzene $(3 \mathrm{~mL})$. The tube was cooled, degassed, sealed off, and heated at $60^{\circ} \mathrm{C}$ for $20 \mathrm{~h}$. The product (7) was isolated from the mixture by silica gel column chromatography (eluent; ethyl acetate $/ n$ hexane $=1 / 7$ (volume ratio) and $1 \%$ of triethylamine). Yield $0.774 \mathrm{~g}(87 \%)$, conversion of $4100 \%$. ${ }^{1} \mathrm{H}$ NMR $\left(\mathrm{CDCl}_{3}\right) \delta: 1.78-1.81(\mathrm{~m}, 1 \mathrm{H}), 2.05-2.06(\mathrm{~m}, 1 \mathrm{H})$, $2.39-2.51(\mathrm{~m}, 2 \mathrm{H}), 2.76-2.87(\mathrm{~m}, 4 \mathrm{H}), 2.96(\mathrm{~d}, 2 \mathrm{H}$, $J=4.8 \mathrm{~Hz}), 3.67(\mathrm{~s}, 2 \mathrm{H}), 4.08(\mathrm{t}, 1 \mathrm{H}, J=4.8 \mathrm{~Hz}), 5.51-$ $5.62(\mathrm{~m}, 2 \mathrm{H}), 7.18-7.33\left(\mathrm{~m}, 5 \mathrm{H}\right.$, aromatic). ${ }^{13} \mathrm{C}$ NMR $\left(\mathrm{CDCl}_{3}\right) \delta: 25.64,30.27,32.77,34.60,38.15,47.20$, $126.70,126.83,128.27,128.40,128.80,128.97,129.41$, 138.39. IR (neat) 3584, 3083, 3059, 3026, 2899, 2825, $1601,1493,1453,1422,1341,1277,1242,1182,1111$, 1071, 1028, 966, 939, 909, 866, 816, 776, 700, 565 $\mathrm{cm}^{-1}$. Anal. Calcd for $\mathrm{C}_{15} \mathrm{H}_{20} \mathrm{~S}_{3}: \mathrm{C}, 60.75 \% ; \mathrm{H}, 6.80 \% ; \mathrm{S}$, $32.45 \%$. Found: C, $61.07 \%$; H, 6.74\%; S, 32.62\%.

\section{Reaction of $\mathbf{5}$ and Benzyl Mercaptan}

The reaction was carried out to obtain the product (8). Yield $84 \%$, conversion of $5100 \% .{ }^{1} \mathrm{H} \mathrm{NMR}\left(\mathrm{CDCl}_{3}\right)$ $\delta: 1.85-2.01(\mathrm{~m}, 4 \mathrm{H}), 2.54-2.58(\mathrm{~m}, 2 \mathrm{H}), 2.97-3.07$ $(\mathrm{m}, 2 \mathrm{H}), 3.58-3.90(\mathrm{~m}, 4 \mathrm{H}), 3.71(\mathrm{~s}, 2 \mathrm{H}), 4.18(\mathrm{t}, 1 \mathrm{H}$, $J=6.8 \mathrm{~Hz}), 5.50-5.59(\mathrm{~m}, 2 \mathrm{H}), 7.21-7.34(\mathrm{~m}, 5 \mathrm{H}$, aromatic). ${ }^{13} \mathrm{C} \mathrm{NMR}\left(\mathrm{CDCl}_{3}\right) \delta: 31.10,31.61,32.85$, $34.61,39.66,52.79,126.71,126.89,127.90,128.44$, $128.96,129.13,129.28,129.45,138.41$. IR (neat) 3061 , 3026, 2915, 2847, 1601, 1493, 1453, 1435, 1292, 1227, 1198, 1071, 1028, 968, 920,829, 765, $700 \mathrm{~cm}^{-1}$. Anal. Calcd for $\mathrm{C}_{16} \mathrm{H}_{22} \mathrm{~S}_{3}$ : C, 61.89\%; H, 7.14\%; S, 30.97\%. Found: C, $62.14 \%$; H, $7.28 \%$; S, 31.28\%. 
Radical Polymerization of Vinylcyclopropanes

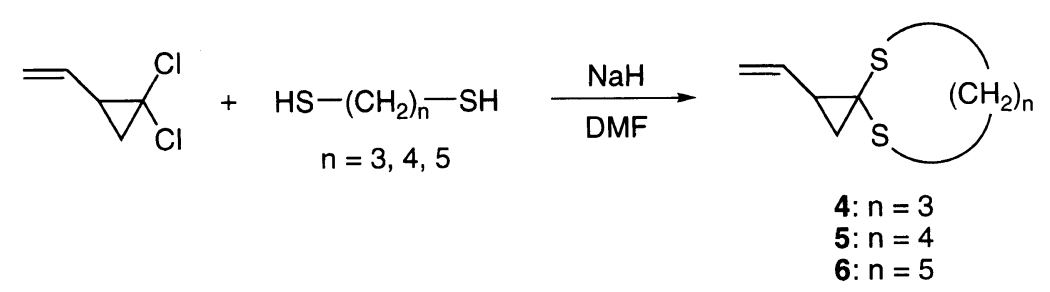

Scheme 2.

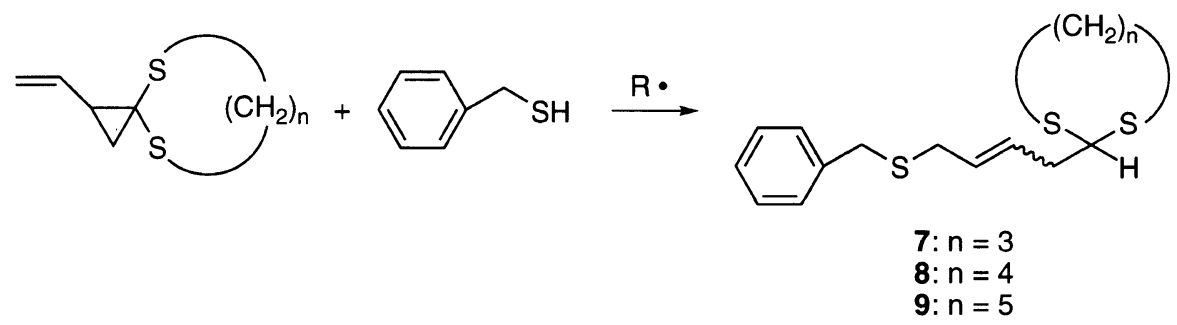

Scheme 3.

\section{Reaction of 6 and Benzyl Mercaptan}

The reaction was carried out to obtain 8 . Yield $83 \%$, conversion of $6100 \%$. ${ }^{1} \mathrm{H}$ NMR $\left(\mathrm{CDCl}_{3}\right) \delta: 1.45$ $1.88(\mathrm{~m}, 6 \mathrm{H}), 2.55-2.85(\mathrm{~m}, 2 \mathrm{H}), 2.98-3.03(\mathrm{~m}, 2 \mathrm{H})$, $3.59-3.80(\mathrm{~m}, 4 \mathrm{H}), 3.67(\mathrm{~s}, 2 \mathrm{H}), 4.03-4.10(\mathrm{~m}, 1 \mathrm{H})$, $5.52-5.59(\mathrm{~m}, 2 \mathrm{H}), 7.21-7.34(\mathrm{~m}, 5 \mathrm{H}$, aromatic $) .{ }^{13} \mathrm{C}$ NMR $\left(\mathrm{CDCl}_{3}\right) \delta: 27.58,28.93,30.30,32.28,33.01$, $34.69,34.78,40.65,55.71,126.88,126.99,127.98,128.38$, $128.62,128.86,129.39,129.61,138.50$. IR (neat) 3083, $3061,3027,1915,2847,2346,1701,1601,1493,1452$, 1435, 1418, 1292, 1229, 1200, 1071, 1028, 968, 920, 829, 766, 700, 498, $413 \mathrm{~cm}^{-1}$. Anal. Calcd for $\mathrm{C}_{17} \mathrm{H}_{24} \mathrm{~S}_{3}$ : C, $64.89 \%$; H, 7.14\%; S, 30.97\%. Found: C, 65.14\%; H, $7.12 \% ; \mathrm{S}, 31.25 \%$.

\section{Radical Polymerization}

General Procedure. To a monomer $(3 \mathrm{mmol})$ in a polymerization tube was introduced an initiator (3 mol\%). The tube was cooled, degassed, sealed off, and heated at a set temperature for $20 \mathrm{~h}$. The polymer was isolated from the resulting mixture by precipitation with $n$-hexane and dried at $50^{\circ} \mathrm{C}$ in vacuo. The polymer was obtained as a pale yellow transparent solid and characterized by GPC, NMR, and IR spectra.

\section{Polymer 4}

Yield 14\%, conversion of $416 \%$. (run 3 in Table I) ${ }^{1} \mathrm{H} \mathrm{NMR}\left(\mathrm{CDCl}_{3}\right) \delta: 1.95$ (broad s, $\left.2 \mathrm{H}\right), 2.66$ (broad s, $4 \mathrm{H}), 2.83$ (broad s, 4H), 5.60-5.77 (m, 2H). ${ }^{13} \mathrm{C}$ NMR $\left(\mathrm{CDCl}_{3}\right) \delta: 25.31,25.91,26.13,41.28$, 52.80, 53.00, 128.66. IR (neat) 3034, 2905, 2828, 1676, 1422, 1273, $1238,968,907,866,735,702 \mathrm{~cm}^{-1}$.

\section{Polymer 5}

Yield $12 \%$, conversion of $513 \%$. (run 4 in Table I) ${ }^{1} \mathrm{H} \mathrm{NMR}\left(\mathrm{CDCl}_{3}\right) \delta: 1.60-2.08(\mathrm{~m}, 4 \mathrm{H}), 2.51-2.72(\mathrm{~m}$, $4 \mathrm{H}), 2.76-3.09(\mathrm{~m}, 4 \mathrm{H}), 5.34-5.87(\mathrm{~m}, 2 \mathrm{H}) .{ }^{13} \mathrm{C} \mathrm{NMR}$ $\left(\mathrm{CDCl}_{3}\right) \delta: 28.20,28.49,31.78,31.99,48.72,115.59$, $117.96,118.16,118.67,134.04$. IR (neat) 3360, 2924, 2855, 2363, 1777, 1682, 1414, 1285, 1017, 912, 731, 646, $461 \mathrm{~cm}^{-1}$.

\section{Polymer 6}

Yield 7\%, conversion of $65 \%$. (run 9 in Table I) ${ }^{1} \mathrm{H}$
NMR $\left(\mathrm{CDCl}_{3}\right) \delta: 1.21-1.80(\mathrm{~m}, 6 \mathrm{H}), 2.39-3.04(\mathrm{~m}$, $8 \mathrm{H}), 5.48-5.93(\mathrm{~m}, 2 \mathrm{H}) .{ }^{13} \mathrm{C} \mathrm{NMR}\left(\mathrm{CDCl}_{3}\right) \delta: 26.12$, $27.19,28.40,31.60,33.92,37.91,116.33,137.01$. IR (neat) $3083,2928,2855,2402,1682,1435,1348,1300,1273$, $1217,1119,1024,990,909,855,741,667,496 \mathrm{~cm}^{-1}$.

\section{Molecular Orbital Calculations}

All computations were done on an Apple Power Macintosh 7100/80 AV using the SONY Tektronix CAChe system version 3.7. Geometries were optimized first with Molecular Mechanics using the CAChe MM2 program and second with Molecular Dynamics using MM2 force field parameters and finally with MOPAC 94 version 3.7 for the CAChe system, using a PM3 Hamiltonian. Calculations were carried out by the restricted Hartree-Fock method for non-radical compounds and the unrestricted Hartree-Fock method for radical compounds. All calculations were done with full optimization of geometrical variables (bond lengths, bond angles, and dihedral angles).

\section{RESULTS AND DISCUSSION}

\section{Monomer Syntheses}

The novel monomers, vinylcyclopropanone six-, seven-, and eight-membered cyclic thioacetals, 1-vinyl4,8-dithiospiro[2.5]octane (4), 1-vinyl-4,9-dithiospiro[2.6]nonane (5), and 1-vinyl-4,10-dithiospiro[2.7]decane (6), were prepared by reactions of 1,1-dichloro-2-vinylcyclopropane with dithioalkoxides obtained from the corresponding dithiols and 2 equivalent of sodium hydride in DMF (Scheme 2). 1,1-Dichloro-2-vinylcyclopropane was prepared according to the previously reported method. ${ }^{5}$ The monomers were identified by ${ }^{1} \mathrm{H}$, ${ }^{13} \mathrm{C}$ NMR, and IR spectra besides elemental analyses.

\section{Model Reaction}

Radical additions of benzyl mercaptan to 4, 5, and 6 as the model reactions were carried out using AIBN as the initiator in chlorobenzene $(1 \mathrm{M})$ at $60^{\circ} \mathrm{C}$ to examine the polymer structure (Scheme 3 ). The reactions proceeded in quantitative conversion to afford the corresponding products $(7,8$, and 9 ) in $83-87 \%$ yields. The structures of the products were determined by ${ }^{1} \mathrm{H},{ }^{13} \mathrm{C}$ 


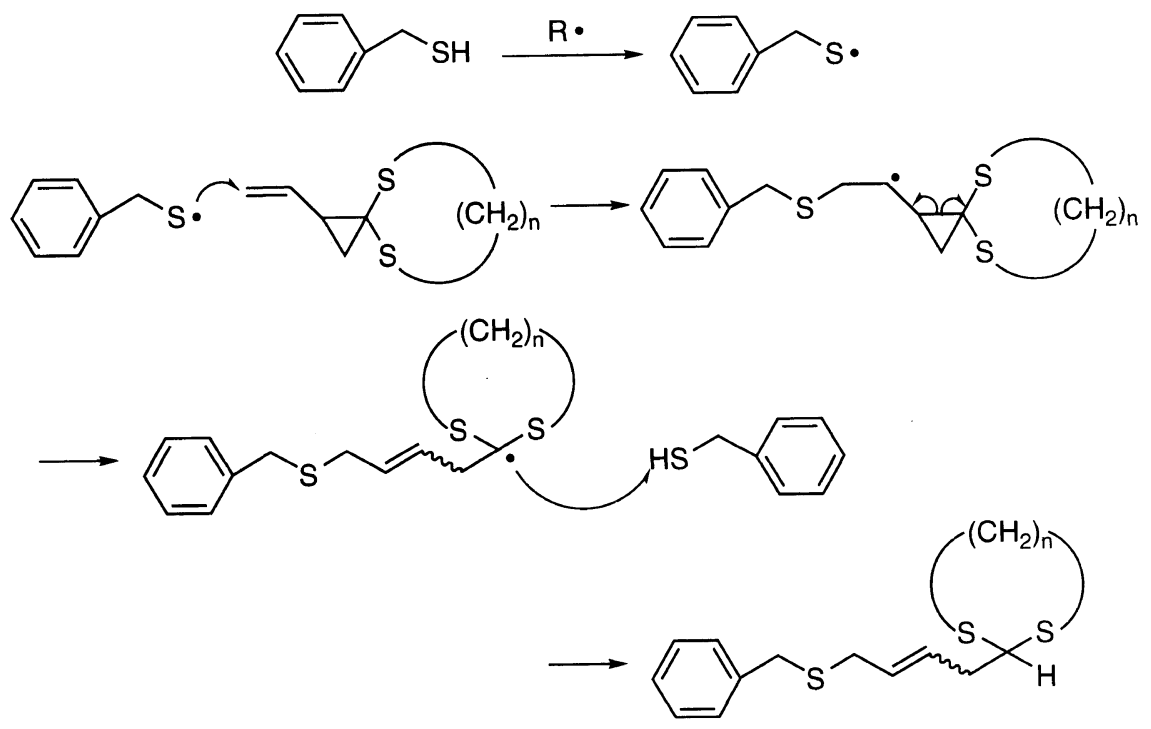

Scheme 4 .

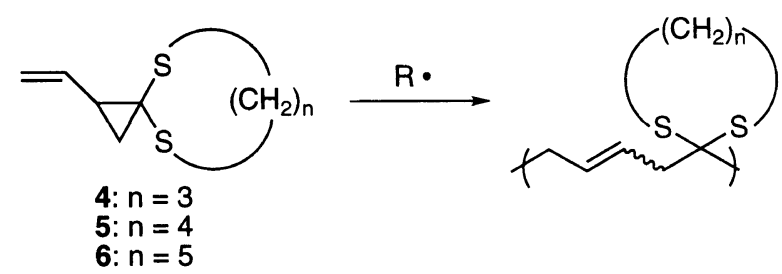

Table I. Radical polymerizations of vinylcyclopropanes bearing cyclic thioacetal moieties ${ }^{\mathrm{a}}$

\begin{tabular}{|c|c|c|c|c|c|c|c|}
\hline \multirow{2}{*}{ Run } & \multirow{2}{*}{$n$} & \multirow{2}{*}{ Initiator } & \multirow{2}{*}{$\frac{\text { Temp }}{{ }^{\circ} \mathrm{C}}$} & \multirow{2}{*}{$\frac{\text { Conv }^{b}}{\%}$} & \multirow{2}{*}{$\frac{\text { Yield }}{\%}$} & \multirow{2}{*}{$\bar{M}_{n}\left(\bar{M}_{w} / \bar{M}_{n}\right)^{\mathrm{c}}$} & \multirow{2}{*}{$\frac{\text { Olefin content }^{\mathrm{b}}}{\%}$} \\
\hline & & & & & & & \\
\hline 1 & 3 & AIBN & 60 & 12 & 8 & $2800(1.28)$ & 67 \\
\hline 2 & 3 & BPO & 80 & 13 & 10 & $2900(1.26)$ & 65 \\
\hline 3 & 3 & DTBP & 120 & 16 & 14 & $2900(1.29)$ & 66 \\
\hline 4 & 4 & AIBN & 60 & 13 & 12 & $3100(1.28)$ & 72 \\
\hline 5 & 4 & BPO & 80 & 8 & 7 & $3000(1.28)$ & 71 \\
\hline 6 & 4 & DTBP & 120 & 10 & 8 & $2900(1.27)$ & 69 \\
\hline 7 & 5 & AIBN & 60 & 6 & 4 & $700(1.13)$ & 84 \\
\hline 8 & 5 & BPO & 80 & 4 & 3 & $600(1.12)$ & 83 \\
\hline 9 & 5 & DTBP & 120 & 7 & 5 & $600(1.14)$ & 83 \\
\hline
\end{tabular}

${ }^{a}$ Conditions: monomer $3 \mathrm{mmol}$, initiator $3 \mathrm{~mol} \%$ vs. monomer, bulk, $20 \mathrm{~h} .{ }^{b}$ Determined by ${ }^{1} \mathrm{H} \mathrm{NMR}$. ${ }^{\mathrm{c}}$ Estimated by GPC based on polystyrene standards, eluent $\mathrm{LiBr}$ solution in DMF (5.8 mM).

NMR, and IR spectroscopy besides elemental analysis. The products, formed by the cleavage of the bonds near the cyclic thioacetal moieties of the cyclopropane rings were obtained, but no doubly ring-opened products. These results were similar to those for radical additions of benzyl mercaptan to vinylcyclopropanes having cyclic acetal moieties. ${ }^{4}$ Scheme 4 illustrates a plausible mechanism of the radical addition of benzyl mercaptan to $4-6$.

\section{Radical Polymerization}

Radical polymerizations of monomers 4,5 , and 6 were carried out at 60,80 , and $120^{\circ} \mathrm{C}$ in bulk using AIBN, BPO, and DTBP in a degassed sealed ampoule for $20 \mathrm{~h}$. The polymers were isolated by precipitation with $n$ hexane containing $1 \%$ of triethylamine to avoid hydrolysis. The obtained polymers were soluble in chloroform and tetrahydrofuran (THF), but insoluble in ether or $n$-hexane.
Table I summarizes the conditions and results of the polymerizations of 4,5 , and 6 . The conversions of 4,5 , and 6 were $12-16,8-13$, and $4-7 \%$, respectively, which were almost equal to the yields of the polymers. Although increase in polymerization temperature would increase conversion of the monomers, it would also increase the termination reaction by abstraction of the allylic hydrogen. Consequently, the conversions of the monomers might be independent of polymerization temperature. Conversions and yields were lower than those of the vinylcyclopropropanone cyclic $O$-acetals. ${ }^{3,4}$ The number-average molecular weights of the polymers $\left(M_{n}\right)$ of 4, 5, and $\mathbf{6}$ were $2800-2900,2900-3100$, and $600-700$, respectively.

The structures of the polymers were determined by ${ }^{1} \mathrm{H},{ }^{13} \mathrm{C}$ NMR, and IR spectroscopy with referring to the model compounds. Figures 1,2 , and 3 show the ${ }^{1} \mathrm{H}$, ${ }^{13} \mathrm{C}$ NMR, and IR spectra of the polymer obtained by 
the polymerization of 4 at $60^{\circ} \mathrm{C}$ (run 1 in Table I), respectively. The absence of signals based on the cyclopropane ring proton (1.07-1.09 and $1.39-1.42 \mathrm{ppm}$ ) in the ${ }^{1} \mathrm{H}$ NMR spectrum (Figure 1) suggests that no cyclopropane ring structure is included in the polymer. The integration ratio of signal $b$ based on the olefin proton to signal $c$ based on the $\alpha$-methylene and signal $d$ based on the $\beta$-methylene protons of the sulfur atoms is smaller than that expected for the polymer that consists only of 10, and thus a polymer unit (13) without an olefinic moiety may be present. No signal was observed

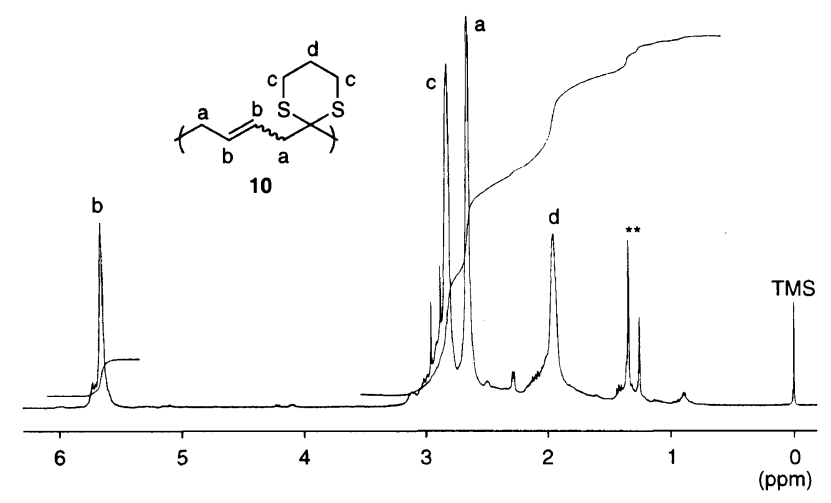

Figure 1. ${ }^{1} \mathrm{H}$ NMR spectrum (solvent $\mathrm{CDCl}_{3}, 400 \mathrm{MHz}$ ) of poly(4). Polymerization conditions: $3 \mathrm{~mol} \%$ AIBN in bulk, $60^{\circ} \mathrm{C}, 20 \mathrm{~h}$ (run 1 in Table I). **: Signal derived from AIBN.

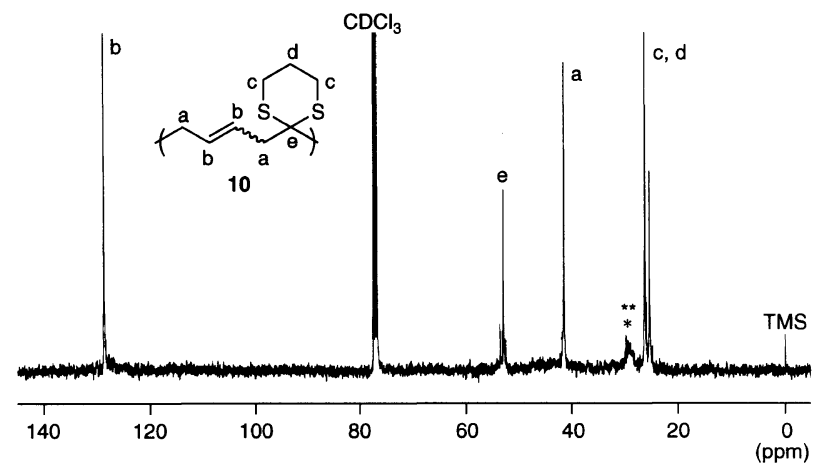

Figure 2. ${ }^{13} \mathrm{C}$ NMR spectrum (solvent $\mathrm{CDCl}_{3}, 100 \mathrm{MHz}$ ) of poly(4) Polymerization conditions: $3 \mathrm{~mol} \% \mathrm{AIBN}$ in bulk, $60^{\circ} \mathrm{C}, 20 \mathrm{~h}$ (run 1 in Table I). *: Signal derived from unit possessing no olefinic moiety. **: Signal derived from AIBN. around $3.7 \mathrm{ppm}$ based on allylic methylene protons $\alpha$ to the dithioester thiocarbonyl group. Thus, no dithioester group, formed by a double ring-opening, was present in the polymer. The ${ }^{13} \mathrm{C}$ NMR signals of poly(4) were assigned as shown in Figure 2. No signal was observed around $240 \mathrm{ppm}$, indicating the absence of a dithioester group formed by the ring-opening of the cyclic thioacetal moiety. No IR absorption at $1200-1020 \mathrm{~cm}^{-1}$ supports the absence of a dithioester group (Figure 3 ). Thus, the obtained polymer was concluded to be formed via 1,5-ring-opening polymerization. This is similar to the radical polymerization behavior of five- and six-membered vinylcyclopropanone cyclic $O$-acetals (Scheme 1). Scheme 5 illustrates a plausible mechanism of the polymerization of 4,5 , and 6 . The unit without olefinic moiety may be formed by the addition of the propagating radical end to the double bond of the polymer main chain. ${ }^{5}$ The detailed structure is not clear due to the difficult characterization of the cyclic structure by NMR spectroscopy. The existence of some branched structures cannot be completely deniable because of the low yields and molecular weights of the polymers, and the broad signals around $28 \mathrm{ppm}$ in the ${ }^{13} \mathrm{C}$ NMR spectrum.

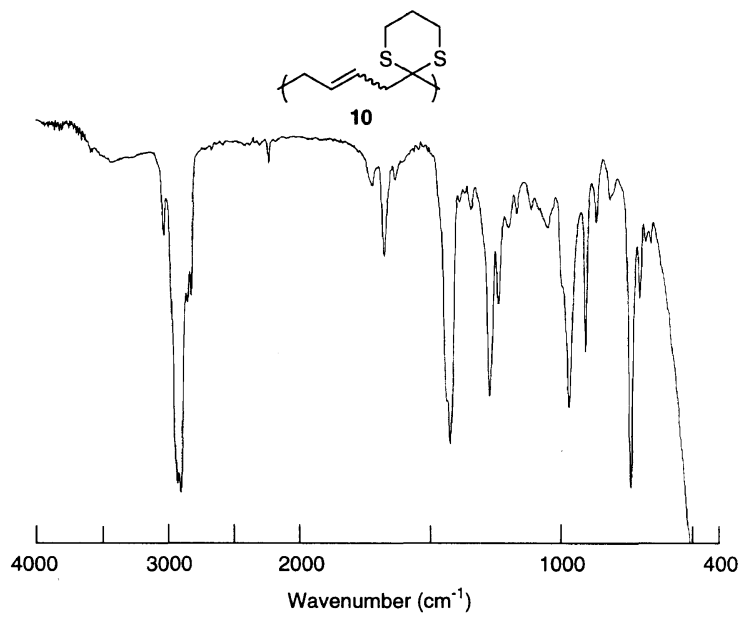

Figure 3. IR spectrum $(\mathrm{KBr})$ of poly(4). Polymerization conditions: $3 \mathrm{~mol} \%$ AIBN in bulk, $60^{\circ} \mathrm{C}, 20 \mathrm{~h}$ (run 1 in Table I).<smiles>C=CC1CC12SCCCN(C)CCCS2</smiles>

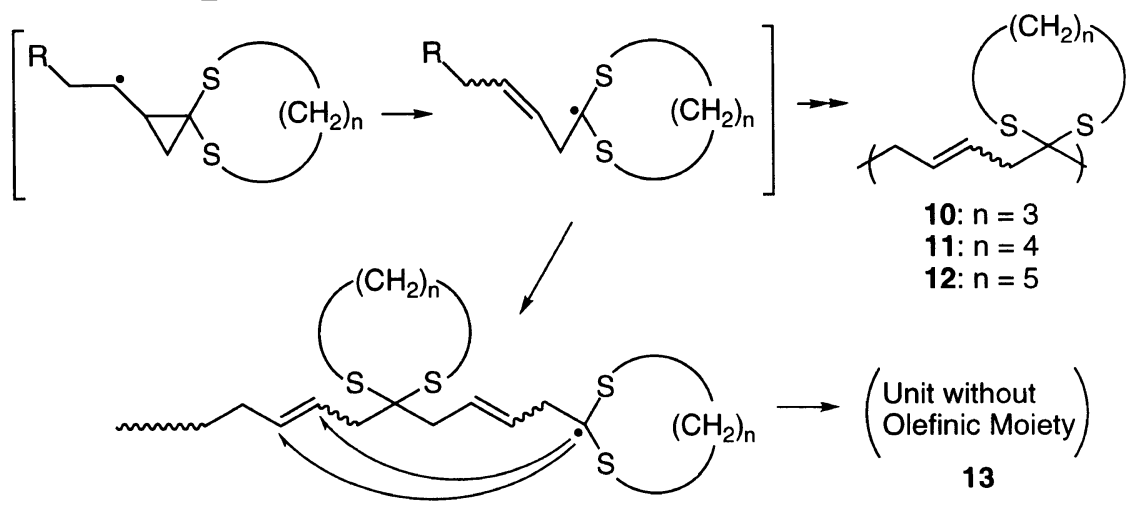

Scheme 5 . 


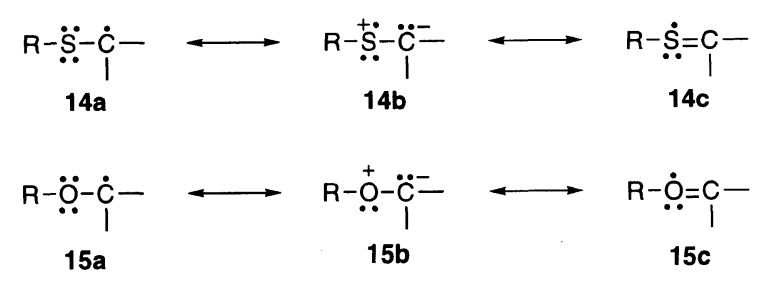

Scheme 6.

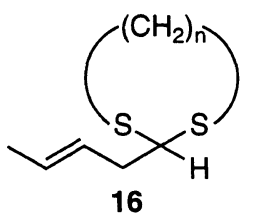<smiles>CC=CCC(=S)SCCCCCC</smiles>

$n=3,4,5$

Table II. Differences in calculated heats of formation for $\mathbf{1 6}$ and $\mathbf{1 7}$

\begin{tabular}{cc}
\hline$n$ & $\frac{\Delta H_{16}-\Delta H_{17}}{\mathrm{kcal} \mathrm{mol}^{-1}}$ \\
\hline 3 & -18.359 \\
4 & -16.018 \\
5 & -10.631 \\
\hline
\end{tabular}

\section{Mechanistic Aspects of Polymerization}

As described above, monomers 4-6 showed lower polymerizability than the vinylcyclopropanone $O$-acetals (1-3), and the bonds near the cyclic thioacetal moieties in the cyclopropane rings were selectively cleaved to afford the ring-opened units. Electron-sharing conjugative effect on the propagating radicals may be the reason for the lower polymerizability and higher selectivity of the bond cleavage of $4 \mathbf{6}$. The radical species substituted by alkylthio group (RS-) is stabilized by $3 \mathrm{~d}-2 \mathrm{p} \pi$ resonance (14c) effect as illustrated in Scheme $6,{ }^{6}$ while the radical species substituted by alkyloxy group (RO-) is not. Stabilization by $\mathbf{1 4 b}$ may be also effective for decrease of polymerizability, since the ionization potential of sulfur is much smaller than that of oxygen. The lower electron negativity of sulfur than that of oxygen, and higher polarizability of $\mathbf{1 4 b}$ than $\mathbf{1 5 b}$ should contribute to the stability of $\alpha$-thioradical. ${ }^{7}$

Molecular orbital calculations were carried out to examine ring-strain of cyclic thioacetal moieties and the selectivity of the ring-cleavage. Table II summarizes the results for differences of heats of formation for single ring-opened model compounds (16) and double ringopened model compounds (17). The heats of formation were negative and larger for all single ring-opened compounds (16) than those for double ring-opened compounds (17) $\left(\Delta H_{16}-\Delta H_{17}=-10.631--18.359\right.$ $\mathrm{kcal} \mathrm{mol}^{-1}$ ). It may be speculated that the single ringopened unit is thermodynamically more stable than the double ring-opened unit. Consequently, only the single ring-opening reaction proceeds. Table III summarizes the two-center energies and bond orders of radical intermediate (18), formed by the addition of methyl radical to the monomer. The more positive the two-center energy, the more easily the bond cleaves. ${ }^{8}$ Therefore, bond $\mathrm{C}_{1}-\mathrm{C}_{3}$ of the monomer should be more easily

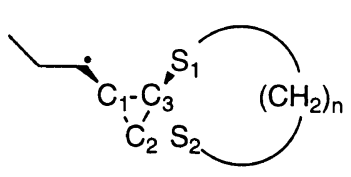

18

Table III. Two-center energies and bond orders of $\mathbf{1 8}$

\begin{tabular}{clcc}
\hline$n$ & Bond & $\begin{array}{c}\text { Two-center } \\
\text { energy/eV }\end{array}$ & Bond order \\
\hline 3 & $\mathrm{C}_{1}-\mathrm{C}_{2}$ & -12.2141 & 0.976 \\
& $\mathrm{C}_{1}-\mathrm{C}_{3}$ & -10.9121 & 0.904 \\
& $\mathrm{C}_{3}-\mathrm{S}_{1}$ & -12.3327 & 0.969 \\
& $\mathrm{C}_{3}-\mathrm{S}_{2}$ & -12.4118 & 0.970 \\
& & & \\
& $\mathrm{C}_{1}-\mathrm{C}_{2}$ & -12.1633 & 0.974 \\
& $\mathrm{C}_{1}-\mathrm{C}_{3}$ & -11.2752 & 0.934 \\
& $\mathrm{C}_{3}-\mathrm{S}_{1}$ & -12.3477 & 0.969 \\
& $\mathrm{C}_{3}-\mathrm{S}_{2}$ & -12.4222 & 0.970 \\
& & & \\
& $\mathrm{C}_{1}-\mathrm{C}_{2}$ & -12.2503 & 0.978 \\
& $\mathrm{C}_{1}-\mathrm{C}_{3}$ & -11.2665 & 0.931 \\
& $\mathrm{C}_{3}-\mathrm{S}_{1}$ & -12.3326 & 0.969 \\
& $\mathrm{C}_{3}-\mathrm{S}_{2}$ & -12.4533 & 0.971 \\
\hline
\end{tabular}
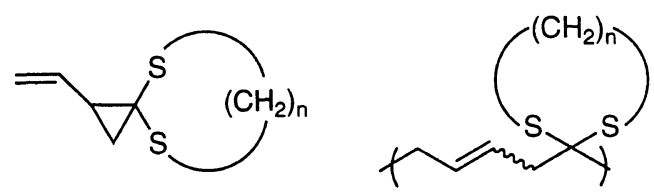

Table IV. Refractive indices of the monomer and polymer

\begin{tabular}{lcc}
\hline$n$ & Monomer & Polymer \\
\hline 3 & 1.538 & 1.661 \\
4 & 1.578 & 1.665 \\
5 & 1.545 & 1.655 \\
\hline
\end{tabular}

cleaved than bond $\mathrm{C}_{1}-\mathrm{C}_{2}$. The bond order of bond $\mathrm{C}_{1}-\mathrm{C}_{3}$ is smaller than that of $C_{1}-C_{2}$, which agrees well with the two-center energy. Bond $\mathrm{C}_{1}-\mathrm{C}_{3}$ of monomers is likely to be cleaved more easily than $C_{1}-C_{2}$. The more negative two-center energy and bond order of bonds $\mathrm{C}_{3}-\mathrm{S}_{1}$ and $\mathrm{C}_{3}-\mathrm{S}_{2}$ than that of $\mathrm{C}_{1}-\mathrm{C}_{3}$ agree with the absence of a double ring-opened unit in the polymer.

Sulfur-containing polymers show high refractive indices. The refractive indices of the monomers and the obtained polymers were $1.538-1.578$ and $1.655-1.665$, respectively (Table IV). The refractive indices of the polymers were larger than those of the corresponding monomers.

\section{SUMMARY}

In this study, the synthesis and radical ring-opening polymerizations of vinylcyclopropanes having cyclic thioacetal moieties, 1-vinyl-4,8-dithiospiro[2.5]octane (4), 1-vinyl-4,9-dithiospiro[2.6]nonane (5), and 1-vinyl4,10-dithiospiro[2.7] decane (6) were carried out. Monomers 4,5 , and $\mathbf{6}$ were synthesized by reactions of 1,1-dichloro-2-vinylcyclopropane and the corresponding dithiols. The radical polymerizations of 4,5 , and 6 
afforded polymers soluble in chloroform and THF, but insoluble in $n$-hexane and ether. The polymers consisted of a unit formed by the single ring-opening of the cyclopropane ring and a unit without an olefinic moiety. No ring-opening of the cyclic thioacetal moiety unit was confirmed. The selectivity of the ring-opening of the cyclopropane ring and no ring-opening tendency of the cyclic thioacetal moiety were also examined by molecular orbital calculations.

\section{REFERENCES}

1. a) T. Takata and T. Endo, in "Expanding Monomers : Synthesis, Characterization, and Application," R. K. Sadhir., Ed., CRC Press, Boca Raton, FL, 1992, Chapter 3.

b) F. Sanda, T. Takata, and T. Endo, Macromolecules, 26, 737 (1993).

2. a) C. Baillet, S. Gandi, P. Breant, and L. Delfosse, Polym. Degrad. Stab., 37, 149 (1992).

b) E. Takiyama and T. Haniuda, Nihon Secchaku Kyoukaishi, 13, 330 (1977).

c) T. Schulze and E. Klemm, Polym. Bull., 31, 409 (1993).

d) D. W. Grijpma, E. Kroeze, A. J. Nijenhuis, and A. J. Pennings, Polymer, 34, 1496 (1993).

e) V. D. Ing, Angew. Chem., 64, 544 (1952). f) W. J. Bailey, Z. Ni, and S.-R. Wu, J. Polym. Sci., Polym. Chem. Ed., 20, 3021 (1982).

3. F. Sanda, T. Takata, and T. Endo, Macromolecules, 27, 1099 (1994).

4. T. Okazaki, F. Sanda, and T. Endo, J. Polym. Sci., Part A: Polym. Chem., 34, 2029 (1996).

5. T. Takahashi, J. Polym. Sci., Polym. Chem. Ed., 6, 403 (1968).

6 a) F. Bernardi, N. D. Epiotis, W. Cherry, H. B. Schlegel, M.-H. Whanbo, and S. Wolfe, J. Am. Chem. Soc., 98, 469 (1976).

b) A. J. Dobbs, B. C. Gilbert, R. O. C. Norman, J. Chem. Soc., (A), 124 (1971)

c) T. Alfrey and C. C. Prince, J. Polym. Sci., 2, 101 (1947).

d) H. J. Alkema and J. F. Arens, Rec. Trav. Chim., 79, 1257 (1960).

7. a) K. Uneyama, H. Namba, and S. Oae, Bull. Chem. Soc. Jpn., 41, 1928 (1968).

b) K. Uneyama, T. Sadakage, and S. Oae, Tetrahedron Lett., 5193 (1969)

c) D. Seebach and A. K. Beck, Ber., 105, 3892 (1972).

d) D. Seebach, H. B. Stegmann, K. Scheffler, A. K. Beck, and K.-H. Geiß, Ber., 105, 3905 (1972).

8. a) F. Sanda, T. Takata, and T. Endo, Macromolecules, 26, 1818 (1993).

b) F. Sanda, T. Takata, and T. Endo, Macromolecules, 27, 3986 (1994)

c) I. Cho and K.-D. Ahn, J. Polym. Sci., Part A: Polym. Chem., 17, 3169 (1979) 